\title{
Dynamic mechanical behaviors of naturally fractured granite subjected to multi-level uniaxial fatigue loads: Insights from fracture and energy evolution analysis
}

\author{
yu wang ${ }^{1}$, xuefeng $\mathrm{yi}^{1}$, bo zhang ${ }^{2}$, and changhong $\mathrm{li}^{3}$ \\ ${ }^{1}$ University of Science and Technology Beijing \\ ${ }^{2}$ Institute of Geology and Geophysics Chinese Academy of Sciences \\ ${ }^{3}$ Affiliation not available
}

June 27, 2020

\begin{abstract}
Multi-level uniaxial fatigue loading experiments were carried out to reveal the fracture and energy evolution of naturally fractured granite using stress strain descriptions and post-test computed tomography (CT) technique. Results reveal the influence of natural fracture on mechanical properties of granite, regarding the fatigue lifetime, fatigue deformation characteristics, fatigue damage, energy evolution and fatigue failure pattern. Volumetric and shear processes caused by the sliding and shearing along the natural fracture control the whole failure process. The energy dissipation and releases characteristics are strongly impacted by natural fractures. The elastic energy and dissipated energy both decrease with increasing natural fracture volume, growth of the dissipated energy becomes faster for rock near to failure. Post-test CT scanning reveals the crack pattern, and failure changes from tensile mode to shear mode with the increasing natural fracture volume. It is proved that the dissipated energy is mainly used to activate the pre-existing natural fractures.
\end{abstract}

\section{Hosted file}

Dynamic mechanical behaviors of naturally fractured granite-submit6.27.docx available at https://authorea.com/users/299009/articles/462979-dynamic-mechanical-behaviors-ofnaturally-fractured-granite-subjected-to-multi-level-uniaxial-fatigue-loads-insightsfrom-fracture-and-energy-evolution-analysis

\section{Hosted file}

table 1.docx available at https://authorea.com/users/299009/articles/462979-dynamicmechanical-behaviors-of-naturally-fractured-granite-subjected-to-multi-level-uniaxialfatigue-loads-insights-from-fracture-and-energy-evolution-analysis

\section{Hosted file}

figure1.docx available at https://authorea.com/users/299009/articles/462979-dynamicmechanical-behaviors-of-naturally-fractured-granite-subjected-to-multi-level-uniaxialfatigue-loads-insights-from-fracture-and-energy-evolution-analysis

\section{Hosted file}

figure2.docx available at https://authorea.com/users/299009/articles/462979-dynamicmechanical-behaviors-of-naturally-fractured-granite-subjected-to-multi-level-uniaxialfatigue-loads-insights-from-fracture-and-energy-evolution-analysis 


\section{Hosted file}

figure3.docx available at https://authorea.com/users/299009/articles/462979-dynamicmechanical-behaviors-of-naturally-fractured-granite-subjected-to-multi-level-uniaxialfatigue-loads-insights-from-fracture-and-energy-evolution-analysis

\section{Hosted file}

figure4.docx available at https://authorea.com/users/299009/articles/462979-dynamicmechanical-behaviors-of-naturally-fractured-granite-subjected-to-multi-level-uniaxialfatigue-loads-insights-from-fracture-and-energy-evolution-analysis

\section{Hosted file}

figure5.docx available at https://authorea.com/users/299009/articles/462979-dynamicmechanical-behaviors-of-naturally-fractured-granite-subjected-to-multi-level-uniaxialfatigue-loads-insights-from-fracture-and-energy-evolution-analysis

\section{Hosted file}

figure6.docx available at https://authorea.com/users/299009/articles/462979-dynamicmechanical-behaviors-of-naturally-fractured-granite-subjected-to-multi-level-uniaxialfatigue-loads-insights-from-fracture-and-energy-evolution-analysis

\section{Hosted file}

figure7.docx available at https://authorea.com/users/299009/articles/462979-dynamicmechanical-behaviors-of-naturally-fractured-granite-subjected-to-multi-level-uniaxialfatigue-loads-insights-from-fracture-and-energy-evolution-analysis

\section{Hosted file}

figure8.docx available at https://authorea.com/users/299009/articles/462979-dynamicmechanical-behaviors-of-naturally-fractured-granite-subjected-to-multi-level-uniaxialfatigue-loads-insights-from-fracture-and-energy-evolution-analysis

\section{Hosted file}

figure9.docx available at https://authorea.com/users/299009/articles/462979-dynamicmechanical-behaviors-of-naturally-fractured-granite-subjected-to-multi-level-uniaxialfatigue-loads-insights-from-fracture-and-energy-evolution-analysis

\section{Hosted file}

figure10.docx available at https://authorea.com/users/299009/articles/462979-dynamicmechanical-behaviors-of-naturally-fractured-granite-subjected-to-multi-level-uniaxialfatigue-loads-insights-from-fracture-and-energy-evolution-analysis

\section{Hosted file}

figure11.docx available at https://authorea.com/users/299009/articles/462979-dynamicmechanical-behaviors-of-naturally-fractured-granite-subjected-to-multi-level-uniaxialfatigue-loads-insights-from-fracture-and-energy-evolution-analysis

\section{Hosted file}

figure12.docx available at https://authorea.com/users/299009/articles/462979-dynamicmechanical-behaviors-of-naturally-fractured-granite-subjected-to-multi-level-uniaxialfatigue-loads-insights-from-fracture-and-energy-evolution-analysis

\section{Hosted file}


figure13.docx available at https://authorea.com/users/299009/articles/462979-dynamicmechanical-behaviors-of-naturally-fractured-granite-subjected-to-multi-level-uniaxialfatigue-loads-insights-from-fracture-and-energy-evolution-analysis

Hosted file

figure14.docx available at https://authorea.com/users/299009/articles/462979-dynamicmechanical-behaviors-of-naturally-fractured-granite-subjected-to-multi-level-uniaxialfatigue-loads-insights-from-fracture-and-energy-evolution-analysis 